This is an Accepted Manuscript of an article published by Taylor \& Francis Group in Journal of Community Archaeology and Heritage on 9 Apr 2019, available online:

http://www.tandfonline.com/10.1080/20518196.2019.1602967.

\title{
Industrial Devon: Reflections and learning from schools-based heritage outreach in
}

\section{Scotland}

Catherine Mills, Ian Simpson, and Jennifer Geller

\begin{abstract}
'Industrial Devon' is a schools-based heritage engagement initiative that staff at the Centre for Environment, Heritage and Policy at Stirling University, Scotland, undertook in 2013/14. The project's implementation involved collaboration with a variety of internal and external education and municipal partners, together with student volunteers. The project explored the environmental history of historic industries located along the River Devon in Clackmannanshire, Scotland, and the associated settlements along its route through the 'eyes' and activities of the local primary school pupils. The year-long project offered a hands-on, experiential approach to knowledge exchange delivery in schools; supplementing the state curriculum and research design for promoting local heritage across community groups of all ages and locations. The reflective narrative on how the initiative evolved, examines the pitfalls and opportunities encountered during planning and implementation and is designed both to inspire and provide a practical tool kit to all considering embarking on similar activities.
\end{abstract}

\section{Keywords:}

Historic Industries, Environmental Legacies, Geo-archaeology, Community Engagement and Student Experience 


\section{The Origins of the Project}

'Industrial Devon' is a university-based, 'outreach to the community' educational project focused on the industrial and environmental history of the River Devon corridor in Clackmannanshire, central Scotland. Environmental history researchers from Stirling University designed the project. The primary objective was to highlight to local young people the river's role both in the county's industrial development and in shaping the communities along its route. In addition, the project also aimed to foster links with the wider community and demonstrate the value of cross-disciplinary teaching and research practice at the University. The project team consisted of Centre for Environment, Heritage and Policy (CEHP) staff members, Catherine Mills and Ian Simpson, who worked in partnership with the Ochils Landscape Partnership (OLP), Sarah Bromage of the Stirling University Art Collection (UAC), Muckhart, Strathdevon, Coalsnaughton, Tillicoultry, Alva and Menstrie primary school teachers and pupils (see Figure 1) and post-graduate and undergraduate Stirling University student volunteers from across academic disciplines (OLP 2017 and UAC 2017). Post-graduate student, Jennifer Geller a formally trained and certified secondary level educator from the USA acted as project support. We delivered Industrial Devon in 2013/14, funded by the Strathmartine Trust, a foundation established by the late Ronald Gordon Cant, to encourage and support the study of Scottish history. The narrative we present here is a collaboration of the project team with individual contributions and comments from the project partners.

<Insert Figure 1 about here>

Industrial Devon owes its origins to a series of free public evening lectures that CEHP staff delivered at the Smith Museum and Art Gallery in Stirling. These aimed to strengthen links with the local community, but also to showcase to a wider audience the Centre's unique approach to environmental history that integrates traditional archival research with earth- 
sciences evidence (CEHP 2017a). The series' success prompted CHEP researchers to explore the possibility of expanding public engagement activities beyond the immediate locality of the University and to a younger audience. The Centre had very limited contact with local schools, particularly in neighbouring Clackmannanshire, and at this point almost no experience of initiating or implementing public engagement. This raised the questions: how do you instigate this kind of project, and can you simply 'cold call' local schools?

As 'academic historians' new to community history, we - the project leads - had no idea of how to begin. Mills was familiar with texts such as Rebecca Conrad's study of Benjamin Shambaugh and the Intellectual Foundations of Public History (2002), Michael William's Researching Local History: A Human Journey (1996). We also were aware of Lindqvist's 1978 notion of 'dig where you stand', the subsequent History Workshop and the idea that historians should both inspire beyond the academy and examine history from the bottom up (Lindqvist, 1978 and http://www.historyworkshop.org.uk/the-history-of-historyworkshop/). We also accessed several volumes of the Open University Series on Studying Family and Community History, for example, Finnegan, Drake and Eustace(1997), but these texts were much more about the historic study of communities, rather than a tool kit offering practical advice on engaging the community in historical research. Given that community history in the UK largely developed out of local history (Twells, 2008), Mills delved into popular studies such as Cooper (2011) and Yarham (2010) Butt (1967). Although largely non-academic texts they were invaluable in helping the team identify features and specific building histories in the wider landscape context.

In terms of project ideas we also drew on local industrial history projects, most of which adopted an oral histories approach such as 'A socio-historical study of the Scottish shale mining communities' (Randall, 1990), Shale Voices (Findlay 2010) and Paper Making on the Water of Leith (McCleery, Finkelstein and Bromage 2006). Mills also trawled the back 
issues of Scottish Local History, the Journal of the Scottish Local History Forum (https://www.slhf.org/) and the publications of Scottish Working Peoples History Trust (http://www.swpht.org.uk/index.php). We did not, however, fully turn to the wider literature, particularly on community archaeology and educational outreach, and we discuss the implications of this decision later on in the paper. We jumped in feet first discovering for ourselves how to initiate, fund, design and manage outreach and public engagement. We effectively learnt as we went along ,becoming aware of important considerations such as risk assessments and the statutory requirements for contact with youth under 18 (i.e. criminal record checks instituted as policy in the UK to safeguard underage children). We resolved the first hurdle of initiating contact with schools through heritage lottery funding of the Ochils Landscape Partnership (OLP) in which the University was a partner. The OLP was a programme based in community involvement and volunteering that aimed to increase access to the hills and glens of the Ochils area, improve the quality of the rivers including the Devon, and restore parts of the historic built landscape (see Figure 1).

We contacted the OLP's research and interpretation officer, Kirsty McAllister, and she approached the primary schools on our behalf. This route offered our outreach activity legitimacy, and there was the initial feeling of a loss of some autonomy over the content of the project, which in hindsight, we realised was the process of true community heritage collaboration. OLP informed the project team that they would work with pupils aged nine to eleven years of age across the six schools in the Partnership's catchment. The school heads also wanted contributions to the primary schools' programme of learning in terms of the Scottish Curriculum for Excellence that would link the schools together collaboratively for their educational system needs (Scottish Government 2016). The OLP also suggested that the project should consider either paralleling or complimenting one of the OLP's three existing project themes, 'Your Wee Bit Hill and Glen', 'By the Banks of the Devon' and 'The Hills of 
Time' (OLP 2017a). As one of the primary aims of our academic outreach was to highlight the field of environmental history for the public, and the benefits of interdisciplinary collaboration within the University community, the project team eventually opted for 'By the Banks of the Devon'. This offered the potential of linking the community schools through the physical landscape of the river corridor. It also provided a vehicle for the development of a wider understanding of the principles of sustainability. This hooked into the curriculum strategy 'learning to live within the environmental limits of the planet' (Scottish Government 2016). Equally, the OLP's focus upon the 'natural' such as re-establishing wetlands, riverbank stabilization and control of alien species provided the opportunity to examine cultural heritage by way of contrast. Although the cultural history of the Devon and its tributaries is largely overlooked, the river played an important role both in the region's industrial development and in shaping the communities along its corridor. This focus tapped into a core research theme within the CEHP; the creation, management, and popular perception and understanding of post-industrial landscapes. Importantly 'the river theme' also strongly intersected a core capability, 'responsible citizens', designated under the government schools' curriculum which ensures that children and young people in Scotland 'develop knowledge and understanding of the world and Scotland's place in it', that they acquire the ability to 'evaluate environmental, scientific and technological issues' and develop informed ethical views of complex issues' (Scottish Government 2016).

\section{Developing the Project's Design Strategy}

Now we had a project idea, and a title, 'Industrial Devon', that sat comfortably with the original project aims. Mills attended a meeting with the school heads, and they approved the ideas, and agreed that the project team would take on the full teaching role within the classroom/field with teachers providing support. The next major step was funding. We found 
our stand-alone outreach plans (i.e. not part of a wider research project) did not fit neatly into our existing major funding streams, and whilst it was possible to bid for travel expenses and materials, it proved impossible to cover staffing costs. Adding student employability to the project aims allowed for rebranding of the project as enhancing the university student experience and we sought the involvement of undergraduate student volunteers. The opportunities that the project offered to enhance student employability skills through liaison with outside agencies made it possible to tap into an internal funding stream ('the Stirling Fund' that supports activities that contribute to University life) that would support the total cost of the project (Stirling University 2017). These financially based decisions improved the project's reach and impact.

The project leads recruited a team of six undergraduate and four postgraduate students drawn primarily from the University's history, environmental science and geography programmes. These volunteers took part in a series of roundtable discussions and workshops designed to flesh out the content and delivery of the project and to equip them with basic skills required for the preparatory research.

Each primary school in the project would focus on a single historic industry that drew water from the Devon or its tributaries for processing, for powering machinery or used the catchment as a sink for waste. As the site location needed to be within walking distance to allow for fieldwork, its proximity to the school premises determined the choice of industry.

Menstrie Primary school explored the history of Doll's whisky distillery with a specific focus on the historic water supply, transport and disposal of potentially contaminated waste from the production process, particularly draff (waste residue from the fermentation of grain), pot ale (waste from the first distillation), and spent lees (residues left in the spirit still). Alva Primary School explored the history of silver mining, the use of water at the site and the problems of mining waste. Tillicoultry Primary School focused on the textile industry and the 
environmental impacts of dying cloth, together with the historic growth of the settlement and its relationship to the industry. Coalsnaughton Primary School examined the environmental legacies of coal mining waste, dereliction and acid mine drainage. Strathdevon Primary in Dollar explored the environmental and social history of the linen bleaching industry at Dollarfield and its relationship to the river Devon. Muckhart Primary examined the history of milling and lime burning at Muckhart Mill and Kilns on the banks of the Devon as well as the associated transport networks. These industries offered the project a broad sweep of the late $18^{\text {th }}$ and $19^{\text {th }}$ century activities within the river catchment. The primarily agricultural site at Muckhart, in the far eastern reaches of the region, operated as the control for the study of the industrial legacies. The plan was to integrate historical source material, existing mapping, visualisation, field work, and laboratory analyses and present it to the school pupils as 'learning to be landscape detectives': how to search for visible (industrial archaeology) and invisible (pollutant) clues. This would be delivered over three sessions, two classroom-based and one in the field, culminating in an integrating exhibition on the river's historic industrial legacy which would link together the six individual school's projects (and the schools). The UAC would host and curate the exhibition, which would also form part of the OLP's annual festival. Each of the six undergraduate students were allocated a school and its associated industry. They each identified and prepared relevant primary source materials and played a key role in the delivery of all three consecutive sessions. The project team and the postgraduate students supported them. The postgraduates were also deployed during the fieldwork to ensure the safety of the school pupils.

The school pupils' participation in the project would provide experiential learning opportunities critical for developing all four capabilities that the curriculum designated, to be successful learners; confident individuals; effective contributors and responsible citizens. Pupils would practice literacy skills and gather evidence from primary sources. They would 
work in groups to make observations through taking soil samples and synthesize their learning in a final poster project. They would also make reasoned evaluations concerning the environmental impact of historic industry on their village, and link history and science to learn in a new multidisciplinary way. The project would also provide pupils the opportunity to develop and communicate their own beliefs concerning the industrial heritage of the River Devon in the final creative writing project, and to gain practice in evaluating environmental issues by considering the conditions that continue to impact on the region. Finally, because of its explicitly community-based focus, the project naturally would require pupils to participate responsibly in their community, resulting in a deeper understanding of its historical and environmental legacy.

Although involving University students in the project was a strategic move in terms of funding, they brought a whole raft of ideas to the table and played a key role in designing the project, crystallising the aims and shaping delivery. They also benefited from their involvement. Volunteering on the project offered them the experience of archival research and environmental investigation and research dissemination albeit in a non-traditional setting, all of which enhanced their employability skills. It was also an enjoyable experience for them, as Undergraduate student volunteer Heather Wilkinson commented, '[ [] $\mathrm{t}$ was great to add a practical dimension to my time studying history at the University and to learn about the local area's industrial past' (pers. com., September 2014). Likewise, Masters student James McKean found it 'interesting to see education in a different environment but also found it quite scary and intimidating to interact with a younger age group who you have no experience with - it's good for confidence building' (pers. com., March 2014).

Unfortunately, despite its new guise, the project still failed to attract financial support via the 'Stirling Fund'. Despite several further applications to local charitable institutions, such as the G \& H Community Trust, which 'focuses on funding small community projects 
that support the advancement of education, community development, human rights, environmental protection, conflict resolution and reconciliation, the project was unsuccessful in its bids'. (http://www.ghrcommunitytrust.org/)

At the time, the University and the academic division did not recognize the value of 'Industrial Devon' in terms of both potential impact and widening local community participation. Although they did not prohibit the project from going forward, they did not support it. There could be no reduction in teaching load, particularly for Mills. It was a choice between either conducting the outreach activities in one's own time or sacrificing contracted research hours that would lead to 'traditional' research outputs that would contribute to the Research Evaluation Framework (REF). REF is the UK's system for assessing the excellence of research in higher education institutions and undertaken by the four UK higher education funding bodies (https://www.ref.ac.uk/about/what-is-the-ref/).

This prompted Mills to make a wider search of the literature, largely to provide justification for the activity which revealed a 'fraught' relationship between academia and 'community history', based around the notion that it is 'amateurish' and lacks rigor and context (Twells 2008). Historian Richard Overy took this a step further to suggest that 'history' is under attack from 'the twin pressures of democratisation and impact', 'history as heritage' and/or a 'public utility'(Overy 2010). This perception of the 'dumbing down' of history offers possible insights into why the Academic Division failed to support the project fully at the time.

By now Mills was in far too deep, and there were too many people to disappoint to consider pulling out. A last resort application to the Strathmartine Trust, which supports research and education on Scottish themes, paid off and the Trust funded materials, travel, and the exhibition costs (Strathmartine 2017). In terms of staff time, we delivered this outside of our contracted academic duties, essentially in our own time. The start of 'Industrial Devon' 
fortunately coincided with the arrival of a Masters student, Geller, on a year's study leave from teaching high school in Providence, Rhode Island. Jennifer willingly took on the role as project support and after a memorable discussion on 'yes the kids will be able to understand the meaning of hypotheses, just wait and see' became our unofficial education advisor. An additional benefit of collaborating with an established organisation such the OLP is that it provided a pool of expertise that we could draw upon, such as Amanda Joaquin, the Clackmannanshire Council Volunteer Officer (CCVO). Amanda had previously worked with all six schools within the context of the OLP. She provided guidance on how to structure our classroom sessions with pupils, particularly in relation to the mix of listening and activity based learning.

\section{Logistics and Partnership Benefits}

Preparation and research were the project's next development hurdles to negotiate. Organizing delivery of the three consecutive sessions around the university student volunteers and the six schools' fixed timetables, together with Mills and Simpson's teaching and other fixed commitments presented logistical difficulties. In addition, the team also needed to ensure that there was sufficient laboratory space and time to analyse and interpret the soil samples, but it all fortunately fell into place with relative ease. The only compromise was that we were unable to start at the source of the Devon and work our way westwards towards the river's confluence with the River Forth. Instead, we followed a somewhat random order starting in the middle with Alva primary school. Mills met with all six class teachers prior to classroom instruction in order to discuss teaching plans. We had to walk and time each route from the school to the river and the sampling sites, and we needed to identify and photograph industrial remains, with the route and site assessed for potential hazards. The locals occasionally spotted CEHP staff in the middle of a field staring patiently at an iPad 
waiting for iGeology to load, much to their amusement. It was a good lesson to learn prior to field work with the schoolchildren: never rely on mobile data and always take laminated hard copies.

With hindsight, high quality outreach was exceptionally demanding in its requirements for workable ideas, integration of a wide range of organisations and individuals, and in its need for effective logistics and delivery. It is as complex as any traditional research project and the 'penalties' of failure just as severe. We should not have assumed that community engagement would garner institutional support and we should have planned more proactively. We encountered one minor difficulty with ethical approval. An active whisky company still owns the site of the historic Doll's distillery (although they no longer distil on site), which was the focus of Menstrie primary school. The company were very helpful and supportive but they were also concerned that the local press could take opportunity to publish the school's visit adversely, along the lines of 'University staff take primary school pupils on whisky trip'. They asked for the project to go to a second ethical committee appraisal to consider this. They also asked to review teaching plans to ensure nothing could be misconstrued as encouraging minors to drink alcohol; insisted on wearing mufti (no logos must be visible) for the children's visit, and wanted the school to be informed of the potential risks.

One need that could have brought the project to an abrupt end could have been the cost of criminal background checks for the students (because of the four-year degree programme in Scotland and potential entry at 17 years of age, university staff employed at the University undergo these routinely). Fortunately, provided the primary schoolteacher was present in class and there were two 'checked' members of staff on the field trip, we were sufficiently covered according to the regulations. In contrast, more traditional scholarly research aspects of the project, such as establishing land ownership to seek permission for the 
visit and sampling was problematic. Another positive aspect of our relationship with the OLP was that they helped us gain access to Clackmannanshire Council landowner maps. Several of the sites had no landowner recorded, suggesting a low value for these small isolated pockets of post-industrial land.

The planning alone again serves to highlight just how demanding the project had become and with hindsight and some distance, bringing it to fruition was a remarkable feat for us. By contrast, the actual historical research of the six industries and their respective sites was relatively easy. The undergraduate volunteers undertook this research, beginning with secondary source reading. Documentary research was primarily desk based using historic maps, images, local periodicals and newspapers and a variety of British Parliamentary Papers. ${ }^{1}$ Mills also carried out some archival research into Erskine and Johnstone family papers, (the historic landowners) and uncatalogued material relating to Doll's distillery. What became clear from the pre-field primary document research was how the local settlements owed their early development to the industries and how the industries were historically linked together not just by the river but the later development of the Devon Valley Railway and also through the use of coal as fuel. This provided the foundation for the project delivery in the schools.

\section{The Project Delivery: Collaborative Community Heritage Education in Action}

The first sessions began in the classroom with a pictorial run through of the river today from its source through the various villages to its confluence with the River Forth using PowerPoint slides. We asked the children how the river is used and how they currently view

it. The responses overwhelmingly concerned leisure - walking, swimming, fishing and canoeing, with some 'farming' use, such as water for cattle. They perceived the river as rural and agricultural, 'the countryside' and 'pretty'. The upper reaches of the Devon pass through 
steep rocky gorges, and the accessible waterfalls, such Devil's Mill and Cauldron Lin are local beauty spots. Several of the pupils had visited them and some were aware that the river also featured in the poetry of Robert Burns in The Banks of the Devon and the Fairest Maid on the Devon (Barke 1968, 435 and 634). The children were unaware that today the river also provides a source of drinking water and generates electricity or that as it meanders broad and flat through its floodplain it had an important industrial past. The one exception to this were the pupils of Tillicoultry Primary school who proudly sported a mill and water wheel as their school logo. They were already aware of how the fast-flowing streams from the Ochils had originally powered the textile industry but were unfamiliar with (and somewhat astonished by) the industry's relationship to the River Devon, which acted as a sink for the wastewater from the washing and dying processes. The reaction to the use and manipulation of the watercourses to serve the county's historic industrial growth was similar across all six schools. The pupils were familiar with the rudiments of current environmental protection. In broad general terms, they understood what was permissible in terms of land and water use but had no concept that this had not always been the case. This provided an ideal route into discussions around sustainability.

To engage the students in the river's industrial past and begin to challenge the current pastoral scene, we taught the children about the wide variety of industries located along the Devon corridor, using historic images and the $18^{\text {th }}$-century plans by James Watt (whom they were all familiar with) to canalize the river. Watt had proposed levelling the riverbed and straightening it course to ease the transportation of coal and goods by boat to market. ${ }^{1}$ The children greeted this with amazement. We then introduced them to some of the remaining industrial archaeological features along the route of the river, the 'visible clues' such as

\footnotetext{
${ }^{1} \mathrm{M} 1 / 3 / 1$ and $\mathrm{M} 1 / 3 / 2-10$ Boulton and Watt Archives, Birmingham Central Library, copies also held by the Dollar Museum, Castle Campbell Hall, High Street, Dollar
} 
weirs, lades, mill buildings, bridge abutments, coppiced trees, hollow-ways (sunken paths), railway embankments and viaduct pillars. Mills specifically noted that it was the remains of viaduct piers that crossed the river Devon just outside Tillicoultry that really engaged the children. They are visible from the road and most were aware of the structures even if they did not know what they were. It was at this point that she explained the project aim of uncovering the industrial history of the river and its important relationship to the development of local communities along it route. The familiarity of the remains of the viaduct made the idea of an industrial past more tangible, it also demonstrated that being a 'landscape detective' was not that daunting and something they could easily achieve.

CCVO Amanda Joaquin had suggested that we break the classroom session into short sections alternating listening with activity, and at this point Geller introduced a mystery picture small group exercise to provide the children with thinking and observations skills for the field session. This was the first practical step to becoming detectives. The pupils were familiar with small group working. We provided each group with an image of either a landscape feature or industrial archaeological evidence and asked them to 'make three hypotheses for what the object might be and the reasons for this', i.e. using incomplete sentences such as 'we think the object is because we see in the photo'. This proved a popular exercise, not least due to the competitive nature that group work appeared to engender. A further PowerPoint presentation followed on from the mystery pictures. This introduced the children to the historical documents and the key facts on their particular industry. The children asked questions, some made observations, for example, 'I know where that is', or made comments such as 'my grandad worked there'. The pupils listened politely but they lacked enthusiasm, and the documents did not fully engage them. As most of the industries we investigated have all but disappeared (except for the mill buildings), there was nothing substantial for the children to hook into (as with the industrial 
archaeology) to bring the past into present day. This was in marked contrast to the active group exercise using maps, which was successful.

We provided the children with a modern map of their local community (see Figure 2), which included their section of the River Devon and industry and a corresponding historic map, together with geological and soil maps in an individual workbook. A handful of the children were familiar with road atlases and street plans from car journeys with their parents, very few were familiar with Ordnance Survey maps. The children took to maps 'like ducks to water' despite their inexperience. They compared historical with current maps through a series of simple questions. These started with the location of their school and home. This facilitated the exploration and understanding of both local landscape changes and the linkages between the industries and the river but also transport networks, urbanisation, and environmental changes such as the construction of weirs and water channels all within a classroom setting.

<Insert figure 2 about here>

In contrast, the geological and soil maps worked better in field, and in the case of Coalsnaughton primary school one eagle-eyed pupil noticed that the village really was built on coal. This fact, as Mills recalled, sent a ripple of astonishment round the classroom, it was nugget of information that they could take home and it provided a tangible link to the heritage of their industrial past through the stories of their parents and grandparents many of whom worked down the pit and it instilled a sense of pride. Coalsnaughton was no longer just Coalsnaughton; it was made of coal.

As student volunteer, Heather Wilkinson also pointed out

it was lovely to hear the children's stories of their family connections to local heritage'. This was an advantage of multiple sessions as opposed to a single visit, you got to know the children better and they brought a wide variety of local knowledge gleaned through their relatives that would be otherwise inaccessible and incorporated it into their understanding (pers. Com., undergraduate history student Heather Wilkinson, November 2013). 
The children took their new skills in 'landscape detection' and their maps into the field. On-route to, and at the sampling site, the children looked for the visible clues (with the help of the student volunteers and staff) to link the landscape to their maps. This worked better for some locations than others, particularly Tillicoultry, where the route followed a mill lade (known as Mill Burn) and included derelict and restored mill buildings adapted for reuse, and at Muckhart, where the historic green lane from the village to the corn mill and limekiln provided the path. At Menstrie, the pupils followed the route of the old railway to the distillery and saw many of the remaining original distillery buildings. The Menstrie pupils also benefited from being able to handle artefacts discovered during the recent construction of a new building, such as old whisky bottles, horseshoes and even a cannon ball.

On site, Simpson, aided by handouts, explained 'hard' rock formation, contrasting volcanic and sedimentary rocks, and 'soft' sediment deposition, considering glacial formations, rock falls and sea level changes, by using what was visible around them (see Figure 3). He linked this into the geological and soil maps, together with the use of rock samples, to understand how the landscape related to the historic location of their village, its mineral resources and its associated industry.

<Insert Figure 3 about here.>

Again, it was bite size information that captured student interest, such as the original width and route of the River Devon during the ice age and the fact that the Alva pupils were standing on what was once a beach (which they could discern by looking at the amount of pebbles and their size). The children, working in their small groups, took soil and water samples (see Figure 4)

$<$ Insert Figure 4 about here>

The school pupils accepted a combination of science and history without question as what environmental historians 'do'. They did not perceive it as either unique or daunting. 
Whereas it raised some mild anxiety amongst the undergraduate history students that they were instructing the pupils correctly, and likewise the science students were clearly not that comfortable when they undertook their historical research for the project. The 'two cultures debate' initiated by C. P. Snow in 1959 clearly continues (Snow 1959 and for more recent discussion see Worster 1996). This raises the question why do disciplinary boundaries become hardened in academic study? Maps interestingly and importantly transcended both disciplines with relative ease.

Dr Paul Adderley and Helen Ewen from Biological and Environmental Sciences at the University analysed the samples using X-ray Fluorescence spectrometry (XRF). They presented the results in simple bar charts with three classes of elements highlighted: 'geology'; 'nutrients', and 'pollutants'. In the third and final sessions in the classrooms, the strategy of listening interspersed with activity continued. Using a 'dummy' XRF machine and imagery, we explained the soil samples analysed and the children received their group's bar charted results along with a periodic table to identify what chemicals their samples contained. They also received background data on 'Soil Metal Concentrations' sourced from Scotland Soil's web pages to compare their 'pollutants' results with background levels (Scottish government 2017). Mills explains what was fascinating was how quickly the pupils understood the science and the intricacies of the task. Astonishingly the periodic table generated much excitement particularly when pupils were able to identity above background levels of contaminants in their samples that could be closely linked to their site's industrial past. Historic pollution, or what one undergraduate student recently termed 'dirty heritage' provided shape and definition to the invisible legacy and it was the 'science' much more than the history that challenged the current perceptions of a rural and bucolic landscape. 
Volunteer post graduate Student James McKean was similarly 'surprised both at how much they [the school children] engaged with the topic' and 'at the depth and complexity of the kids’ questions' (pers. com., James McKean, March 2014).

\section{Collaborative Research Findings}

The sample results were used to tap into notions of soil quality in terms of plant nutrients and current land use but the pupils' key focus and enthusiasm was for the 'hidden clues' and what the soil could reveal about their community's industrial past. They were not disappointed. The children identified copper concentrations above expected background levels in several of the samples at the site of Doll's distillery in Menstrie. This suggested that the processing waste was potentially used to either feed livestock or spread on the surrounding land as fertiliser. At the foot of the Glen in Alva, the samples revealed very low but evident concentrations of silver from mining activities high on the hillside. We identified chromium in the samples taken at the confluence with the River Devon and Mill Burn at Tillicoultry, which may be either naturally occurring from the bedrock or washed downstream resulting from the dyeing process. Chromium was used by the historic dying industry as a mordant to fix the colour to the wool. At Tillicoultry mine at Coalsnaughton, the children found high levels of calcium leached from the bedrock in their water sampling. This effectively neutralised the water drainage from the mine ( $\mathrm{pH}$ 6.5) before it reached the Devon reducing the problems of acid mine drainage. This was evidence of nature repairing itself. At the site of the Dollarfield works, above background levels of chlorine were present across the site and most likely associated with the bleaching process. At Muckhart Mill, the children discovered high levels of calcium in their samples adjacent to the limekilns. The team expected this result but the sample also revealed zinc, which indicated that the limestone burnt in the kiln was not local. This raised interesting speculation not so much around why and where the zinc 
came from, but how it might have been transported to Muckhart, given the isolated and remote location.

This was not robust science, the landowners' permissions and the children's safety largely determined the sampling sites, rather than a rigorous attempt capture accurately the industrial legacy. This was essentially random sampling. Yet the activity highlighted the wealth of hidden history contained within the environmental record. Traditional historians often ignore this, yet it can effectively plug the gap when the archival record is sparse (for an example see, Mills, Simpson and Adderley 2014). The exposure of the specific contaminants concealed within that record also opened a window for the schoolchildren onto an increasingly forgotten and overlooked industrial past. This suggests that historic pollution, albeit 'dirty' and occasionally harmful, has its own unique heritage value.

To link the class-based and field sessions together the schoolchildren produced a team poster and their class teachers initiated 'subsequent' creative writing and drawing activities. These both charted the pupil's discoveries as landscape detectives and explored perceptions of what life or work in the historic industry might have been like. The University Art Collection displayed the posters and a selection of this work in the University's public art space in conjunction with Ochils festival in June 2014. Although it was not an objective of the project, the children's creative work offered an insight into their perceptions of postindustrial landscapes. In contrast to the common perceptions of ugly and abandoned and associations of deprivation and ill- health (Bambra et al. 2014 and Maantay 2013), the children's poetry revealed a much more positive view, often charting historic damage through to repair and/or healing associated with current rural perceptions of the river Devon. They were also less 'black and white' in their perceptions and portrayed the industrial, 'grey smoke belching from mill chimneys' juxtaposed with the rural 'long grass blowing in the wind', 'birds chirping with joy' and 'glorious flowers beside me'. A pupil from Tillicoultry primary, 
for example, described the journey of a droplet of water through the mill. At first, the droplet witnesses 'birds tweeting in the tall trees', 'sweet fresh air' that 'smells good', followed by squeaky creaking from the water wheel' 'little children working' and 'horrible dye coming from the wool' through to 'free now I am back in Mill Burn'.

\section{Project Legacies}

We did not consider any measurement of the project's impact or legacy in its planning. The time constraints and tight budget resulted in a lack of follow-up or implementation of measures to obtain formal feedback from the schools. The overwhelming response to the completion of the classroom and field activities was that we had hugely enjoyed it, but also a sense of relief that 'against all odds' we had actually managed to deliver the project. With hindsight had we perhaps consulted a wider literature, for example from community archaeology, we would have understood the importance of building formal evaluation of the impact on the schoolchildren and their families into the project. Also we could have taken into account the notion that the wider community willingness to engage with the project was also a measure of its success and indicated a strong outcome.

Industrial Devon had given the pupils a sense of place built upon the cultural heritage of the river's industries and their community's role in Scotland's historic social and economic transformation, but the team had no idea if this would sustain beyond the project. Student volunteer James McKean was much more optimistic. He wondered 'if it [contact with the University] might open up life opportunities for the kids in the future so that they [the schoolchildren] have more options than their parents and grandparents' (pers. com., March 2014).

The project culminated in a public exhibition. Sarah Bromage from the UAC launched the event on $7^{\text {th }}$ June 2014, roughly six weeks after the final classroom and field 
sessions (see Figure 5). This was less well attended than we would have wished and despite extensive personal invites, that Tillicoultry Primary School pupils designed, sent out to everyone who had been involved in the project, together with publicity via the OLP's annual festival, the UAC and the local press. There was no representation from wider academic division or the University. The project formally ended with a short 'write up' together with selection of the children's creative work published on the CEHP's website (CEHP 2017b). We made the teaching materials available for anyone to copy and/or adapt; again, we made no provision to record viewing or use. The project team chalked Industrial Devon up as a positive experience but one that we would not choose to repeat.

$<$ Insert Figure 5 about here>

Over time, qualitative positives in terms of the project's legacy emerged. The pupils' work was formally exhibited until August 2014 in the public art space; it was fortuitously on route to the cafeteria and attracted a significant amount of interest from staff and students particularly given that this was the first time space had been allocated to a collaborative school project rather than displaying formal art collections. Unfortunately, the exhibition comments book mysteriously disappeared at the end of July leaving only recalled readings of the comments available for posterity:

The comments as best as I can remember can be summed up in two themes, collaboration and heritage, many people remarked that this is what a university should be doing and were delighted to see engagement with the local community and it was good to see children exploring their local heritage (pers. com., Sarah Bromage, August, 2014).

One resident of Coalsnaughton/Tillicoultry area commented (in the replacement book) 'even as a local, I did not realise what heritage we had'. Comments at the exhibition launch included that of a retired miner who had worked at Tillicoultry mine, stating how pleased he was to know that what he thought of as 'his personal history' was of interest to the wider community particularly the younger generation. 
The project exhibition enabled the UAC to expand its community links and introduce 'schools work' as a major new focus of their collection. We were invited back to Alva Primary School to tell the story of the silver mine to the younger primary school pupils, and this activity was subsequently linked into a treasure hunt based upon the alleged hidden hoard of silver ore (Moreton 2008, 15). We learnt that the Menstrie school pupils created posters on 'doing environmental history' and we were invited back for a classroom session.

Coalsnaughton School followed up science sessions based around the XRF machine and the laminated handouts have provided a resource for teachers.

At the tertiary level, project outcomes include Mills incorporating elements of the environmental and industrial history of the Devon corridor, particularly in relation to current flooding and the legacies of coal mining at Coalsnaughton, into an undergraduate history module that explores the use, abuse and protection of the environment in $20^{\text {th }}$ Century Britain. Simpson has incorporated the project into the 'relevance's' seminar within his Honours year Geo-archaeology module. The project has also operated as a spur for Mills to put together a research funding application to examine social and cultural values of postindustrial dereliction from a community perspective.

Mills and Geller have also begun to recognise that 'Industrial Devon' actually offered a flexible research design for community engagement that can be rolled out and adapted across a wide variety of community groups, locations and themes whilst offering a unique and rapid method of public dissemination of environmental history that is also transferable across international borders

The design allowed it to fit within both Scottish and American national curriculum frameworks. While the content of the Industrial Devon project would not be directly relevant to American students, its general framework is adaptable to the Common Core State Standards, currently used widely throughout the USA to guide curriculum development 
(Common Core Standards Initiative 2016). The various stages of the Industrial Devon framework facilitates tasks such as integrating and evaluating multiple sources of information in order to solve a problem, evaluating hypotheses and data, and presenting information, findings, and supporting evidence with a distinct perspective. As Geller explains, in Providence, Rhode Island, the birthplace of American manufacturing, she has begun to pilot a project adapting local industrial history to the model with her pupils at Central High School. From 1896 to 1996, Gorham Silver, the world's largest silver manufacturer, occupied the banks of Mashpaug Pond, Providence's largest fresh-water body. Her pupils first undertook a desk-based study of the history of Gorham Silver, the pond, and the surrounding neighbourhoods, utilising maps as well as primary and secondary sources. Then, they took a field trip to the site of the former factory where science teacher David Evans described the environmental aspects of the space, in particular, on-going remediation efforts. The space is still in remediation and yet not open to the public, so no soil or water testing by pupils has taken place. Once this space opens to the public in summer 2018, sampling will be an option, as well as opening-up the possibility for pupils to participate in the air quality monitoring currently conducted by the Rhode Island Department of Environmental Management.

Back at in the classroom, the Central High pupils that Geller teaches studied the pros and cons of various options for re-purposing vacant and derelict land, including using the space for schools, as is the current use of one of the Gorham site parcels (Gould, Carlson and Sadie 2016). Some pupils having chosen a different brownfield site in Providence wrote letters to city council and designed posters advertising their proposed remediation and re-use of their selected sites. Clearly, then, the Industrial Devon design can be adapted not only to meet local pedagogical goals, but also can be adopted by any school seeking to deepen its pupils' connections to their community's heritage.

Another important aspect of the project's design is the way in which it expands the 
notion of heritage itself. When asked for their initial impressions about the importance and usage of the River Devon, pupils always spoke first of its natural heritage: fishing, boating, swimming, recreation. On the other hand, Providence pupils' perspective of their city's industrial heritage can be best summed up in the words of Central High School pupil Edwin Roja, who asked, 'if we know Providence is crap, why do we have to talk about why it's crap?' In both Scotland and the USA, then, the design framework serves as an important tool to challenge the accepted local perception of heritage. In Scotland, the project increased awareness of the River Devon's industrial heritage and its complicated interaction with the natural environment. In Providence, the project awoke in pupils the concept that an urban, industrial environment does not preclude a natural heritage.

It also allows pupils to contribute to the development of the heritage of their communities. For the older US pupils in Providence, the idea of reimagining a city's heritage can translate into career development, including public activism; urban planning, local government, environmental monitoring and brownfield clean up. By making their work public, pupils at all levels write themselves into the story of their community, and heritage becomes an on-going process of which they are a part.

The dissipation over time of the initially limited perception of the project, a marked shift in attitudes towards public engagement by the University and the appointment of heritage colleagues with backgrounds in archaeology and anthropology prompted a desire to share the team's experiences more widely and formally evaluate the project. It was at this point, that the team lead Mills turned particularly to the wider literature. We could simply measure our outcomes against the projects aims as discussed above but was that enough? Were we missing a recognised set of criteria to measure its value and impact?

With the exception of examples of how to embed public history into UK higher education, there was no practical guide for historians on either implementing public 
engagement projects or their evaluation (Beals 2017). A suggested search of the community archaeology literature proved more fruitful, and again this highlights the value of stepping outside of traditional discipline boundaries. Simpson and Williams had raised similar questions relating to evaluation and proposed two methodologies, 'evaluation by selfcritique' and 'evaluation by external appraisal and comparison' (Simpson and Williams 2008; Simpson 2008). We were probably overly cautious in our evaluation at the immediate end of the project but the process of time, informal review driven by curious peers, rather than formal external appraisal that led to the recognition of the positive perception of outcomes.

\section{Conclusion}

The outreach component of the project when it began in 2013, for both the Division of History and Politics and the University, was ahead of its time. It was unsupported and misunderstood, perceived by some as attempting to opt out of contractual teaching responsibilities. Now the University's 'vision, values and purpose' has shifted. A key section on 'Partnership and Public Engagement' and the shift towards research dissemination beyond academia and its subsequent effect on society driven by REF 2021 is written into the new strategic plan for 2016-2021. Projects akin to Industrial Devon are now actively encouraged (Stirling University 2016). There are also formal mechanisms in place, operated by the University's Students' Union, for the recruitment of student volunteers on research projects as part of employability strategies (Stirling Students' Union 2013).

Funding outreach or public engagement activities, however, remains a dilemma that has not been resolved. Rather than stand-alone projects, community engagement is perhaps best incorporated into wider research projects as dissemination and/or impact. Despite Industrial Devon's inconspicuous origins, the project generated small but expanding ripples of impact, in personal teaching practice, new projects and future directions of research. Above all the staff and students who worked with the schools agreed that the project instilled 
a sense of pride in the children and that this spread to their families, measured by their enthusiasm and participation and the stories that the children passed on to us from their parents and grandparents. With the children operating as catalysts in drawing out identities founded on local heritage we avoided the tensions (again by default rather than reference to the literature) of a 'top down' approach (Cobb, Giles and Jones 2011) and the project moved from schools-based heritage outreach to genuine public engagement. Nowhere was that more obvious then when the Alva pupils discovered the silver in their soil samples and the realisation that where they lived had a significant history. We hope that we have sown seeds of interest; both in terms of their local heritage and in the wider context of environmental history and this may prove fruitful for the future.

\section{Acknowledgements}

Special thanks go to the Strathmartine Trust for generously funding the project (04719); the pupils and class teachers of Alva, Coalsnaughton, Menstrie, Muckhart, Strathdevon and Tillicoultry primary schools. The student volunteers: Euan Burt (Environmental Science); Alison Chidwick (Environmental Geography); Lauren Dixon (Environmental Science and Politics); Katy Jack (History PhD); Christopher McKay, (MSc in Environment, Heritage and Policy); Eilidh MacRaild (Environmental Geography); James McKean (MSc in Environment, Heritage and Policy) and Heather Wilkinson (History). The landowners for allowing the children to sample the soil/water: R Marshall; Sterling Mills; Dollarfield Caravan Park; E Geddes (Straith Estates); Julian Bell, Muckart mill and Mr. Ally Paul (Diageo). The unfailing support of Bill Jamieson (mapping); Ronnie Balfour (equipment); Dr. Claire Wilson (Tillicoultry field work); Dr. Paul Adderley (analysis and charts); Dr. Shane MacLeod (field work support); Helen Ewen (water analysis); Janet Carolan at Dollar Museum; Alloa Archives and Library; Dr. Kirsty McAllister (OLP) and Amanda Joaquin (CCVO). 


\section{Bibliography}

Barke, James, ed. 1968. Poems and Songs of Robert Burns, reprint, Glasgow: Collins

Butt, John, 1967. The Industrial Archaeology of Scotland, Newton Abbot: David and Charles

Bambra, Clare, Steve Roberston, Adetayo Kasim, Joe Smith, Joanne Marie Cairns-Nagi, Alison,Copeland, Nina Finlay and Karen Johnson. 2014. 'Healthy Land? An Examination of the Area Level Association between Brownfield Land and Morbidity and Mortality in England', Environment and Planning, 46: 433-454. doi:10.1068/a46105

Beals, M. H., ed. 'Public History in UK Higher Education'. The Higher Education Academy. Accessed March 2017.

https://www.heacademy.ac.uk/system/files/cs_various_publichistoryinhe_20110117.pdf

Centre for Environment, Heritage and Policy. 2017a. 'Outreach and Public Engagement/ Landscape Encounters'. Accessed March 132017.

http://www.stir.ac.uk/cehp/outreachandpublicengagement/landscapeencounters/

Centre for Environment, Heritage and Policy. 2017b. 'Outreach and Public

Engagement/Industrial Devon. Accessed March 2017.

http://www.stir.ac.uk/cehp/outreachandpublicengagement/industrial-devon/

Cobb, H., m. Giles, M. and S. Jones. 2011. 'Partnership in the Park: exploring the past, inspiring the future in inner-city Manchester' The Archaeologist, 82: 20-1

Common Core State Standards Initiative, 'Science and Technical Subjects Grade 11-12', and 'Speaking and Listening Grade 11-12'. Accessed 12 July 2016.

http://www.corestandards.org/ELA-Literacy/.

Conrad, Rebecca. 2002. Benjamin Shambaugh and the Intellectual Foundations of Public History, Iowa City: University of Iowa Press

Cooper, Tim. 2011. How to Read Industrial Britain: A Guide to the Machines, sites and Artefacts that Shaped Britain, London: Ebury.

Douet, James, ed. 2012. Industrial Heritage Re-tooled The TICCIH Guide to Industrial Heritage Conservation, Lancaster: International Committee for the Conservation of Industrial Heritage

Drake, Michael, ed. 1994. Time, Family and Community, Perspectives on Family and Community History, Oxford: Blackwells.

Findlay, Alistair. 2010. Shale Voices: A Creative Memoir of Scotland's Oil Shale Industries, Edinburgh: Luath

Finnegan, Ruth, Michael Drake and Jacqueline Eustace, eds.1997. Sources and Methods for Family and Community Historians: Volume 4, (Studying Family and Community History), Cambridge: Cambridge University Press in Association with the Open University. 
Gould, Erik, Carlson, Erik, and Sadie, Joshua. 2016. 'Rhode Island Art In Ruins'. Accessed July 2016. http://www.artinruins.com/arch/?id=historical\&pr=gorham\#.

History Workshop. 2018. History of the History Workshop. Re-accessed November 2018. http://www.historyworkshop.org.uk/the-history-of-history-workshop/.

Lord, Barry and Maria Piacente. 2014. Manual of Museum Exhibitions, 2nd Edition, Plymouth: Rowman \& Littlefield

Sven Lindqvist, 1978. Grav Dar Du Stat, Stockholm: Bonnier

Maantay, Juliana A. 'The Collapse of Place: Derelict Land, Deprivation, and Health Inequality in Glasgow, Scotland'. Cities and the Environment (CATE): 6, 1, Article 10. Accessed March 2017 http://digitalcommons.lmu.edu/cate/vol6/iss1/10.

Mathias, Peter. 1969. The First Industrial Nation: An Economic History of Britain 17001914, London: Methuen

McCleery, Alistair, David Finkelstein and Sarah Bromage, eds. 2006. Paper Making on the Water of Leith, Edinburgh: Berlinn

Mills, Catherine, W. Paul Adderley and Ian Simpson. 2014. 'The Lead Legacy: The relationship between historical mining, metallurgical practices and heavy metals contamination' Landscape History, 35, 1: 47-72. doi: 10.1080/01433768.

Moreton, Stephen. 2008. Bonanzas and Jacobites: The Story of the Silver Glen Edinburgh: National Museums of Scotland.

National Library of Scotland, 'Map Images' re-accessed November 2017. http://maps.nls.uk/.

Ochil's Landscape Partnership. 2017. 'Home Page'. Accessed March 2017.

http://ochils.org.uk

Ochil's Landscape Partnership. 2017a. 'Projects'. Accessed March 2017.

http://ochils.org.uk/projects

Overy, Richard. 2010. 'The Historical Present'. Times Higher Education. Accessed March 2017 https://www.timeshighereducation.com/features/the-historical-present/411360.article

Pryce, W. T. R., 1994. From Family History to Community History, Volume 2, (Studying Family and Community History), Cambridge: Cambridge University Press in Association with the Open University.

Randall, Sara. C. 1990. A Socio-Historical Study of Scottish Shale Mining Communities in Mid and West Lothian, Institute of Occupational Medicine, Historical Research Report TM/90/02 available at https://www.iom-world.org/pubs/IOM_TM9002.pdf. Re-accessed November 2018.

Research Excellence Framework, REF 2021, 2017, 'What is the REF?' re-accessed November 2018. https://www.ref.ac.uk/about/what-is-the-ref/ 
Scottish Government. 2016. 'Curriculum for Excellence'. Last modified June 2016. http://www.gov.scot/Topics/Education/Schools/curriculum

Scottish Government. 2017.'Welcome to Scotland's Soils' Last modified March 2017. http://soils.environment.gov.scot/.

Scottish Local History Forum, People, Places and Pasts, 'Home Page'. Re-accessed November 2018. https://www.slhf.org/

Scottish Working Peoples History Trust. 2018. Home Page. Re-accessed November 2018. http://www.swpht.org.uk/index.php..

Shaw, John. 1983. Water Power in Scotland, Edinburgh: John Donald

Simpson, Faye. 2008. 'Community Archaeology under Scrutiny', Conservation and Management of Archaeological Sites, 10, 1: 3-16. doi: 10.1179/175355208X404303

Simpson, Faye and Howard Williams. 2008. 'Evaluating community archaeology in the UK' Public Archaeology, 7, 2: 69-90. doi: 10.1179/175355308X329955

Snow, Baron Charles Percy. 1959. 'The Two Cultures. Paper presented at the Rede Lecture Series, University of Cambridge, May 1959. Re-accessed February 2019. http://s-fwalker.org.uk/pubsebooks/2cultures/Rede-lecture-2-cultures.pdf

Stirling Students' Union. 2013. 'Employability'. Last modified 2013.

https://www.stirlingstudentsunion.com/employability/star/

Stirling, University of, 'Strategic Plan 2016-2021', March 2016.

http://www.stir.ac.uk/about/our-strategy/?o=/

Stirling, University of. 2017. 'The Stirling Fund'. Accessed March 2017.

http://www.stir.ac.uk/alumni/support-stirling/the-stirling-fund/

Strathmartine Trust. 2017. 'Welcome to the Strathmartine Trust' Last Modified 2017 http://www.strathmartinetrust.org/

Swan, Adam. Clackmannan and the Ochils: A Illustrated Architectural Guide, Edinburgh, The Rutland Press

Tiller, Kate. 2002, English Local History: An Introduction, Stroud: Sutton.

Twells, Alison. 2008. 'Community History'. Institute of Historical Research. Accessed March 2017

http://www.history.ac.uk/makinghistory/resources/articles/community_history.html

University Art Collection. 2017. 'Welcome to the Art Collection'. Accessed March 2016. http://www.stir.ac.uk/artcol/.

Welsh, Tom. 2009. Local History on the Ground, Stroud: The History Press. 
Whatley, Christopher, A. 1997. The Industrial Revolution in Scotland, Cambridge:

Cambridge University Press

Williams, Michael, A. 1996. Researching Local History: A Human Journey, Abingdon: Routledge.

Worster, Donald. 1996. 'The Two Cultures Revisited: Environmental History and the Environmental Sciences', Environment and History, 2: 3-14.

Yarham, Robert. 2010. How to Read the landscape: A Crash Course in Interpreting the Great Outdoors, London: Herbert

$\underline{\text { List of Figures for 'Industrial Devon': Reflections and learning from schools-based heritage }}$ outreach

Figure 1. Location map/OLP catchment (C) Clackmannanshire Council

Figure 2 Sample pages from Alva Primary School pupil's workbook (C) Catherine Mills

Figure 3 Laminated handouts depicting 'hard' rock formation and sediment deposition (C) Ian Simpson

Figure 4 Jennifer and Tillicoultry Primary School pupils recording soil colour using a Munsell chart (C) Heather Shrimpton, P7 class teacher, Tillicoultry primary school Figure 5 Visitors admiring the pupils' posters at the Exhibition Launch (C) Sarah Bromage

\footnotetext{
${ }^{1}$ National Record of Scotland, Edinburgh, Erskine-Murray papers GD1/44/7/5-13, Clackmannanshire Archives, Archives and Local History Services, Spiers Centre, Alloa, Johstone of Alva papers, PD239 uncatalogued collection and Papers relating to Glenochil Distillery, PD118
} 